\title{
Dilemma of Chinese Art History Course and the Countermeasures
}

\author{
Jingshu $\mathrm{Li}^{1, \mathrm{a}}$ \\ ${ }^{1}$ Hankou University, Wuhan 430073,China \\ alijingshu@126.com
}

Keywords: Chinese art history course; Institutions of higher learning; Teaching materials

\begin{abstract}
Based on study of the history of professional art Chinese art course and its current situation in universities, it was pointed out in the paper that marginalization difficulties the current institutions of higher learning specializing in Chinese art history art courses facing, and the plight of the formation of external and internal factors are analyzed in detail. On this basis, by focusing around the basic norms of the main stylistic features and materials, college art professional Chinese art history textbook constructions were mainly discussed. Finally, it was proposed that as for art major Chinese art history course in university, we should pay attention to transform from traditional knowledge to instill injection teaching to research study that improving students' ability. These studies are conducted in order to provide useful references for institutions of higher learning on the fine arts theory curriculum reform.
\end{abstract}

\section{Background}

\subsection{Marginalization of Chinese art history courses}

Brilliant Chinese civilization has a long history with a good tradition. Study on Chinese art history also started long time ago. From the first known more complete Chinese art history book, "art history in mind," the study can has be conducted for 1161 years, 700 years earlier than the first books in Western art history. But Chinese art history teaching and research in higher art education system was a product of modern western learning, far behind Germany, Switzerland, Austria and other German-speaking countries. In the first year (1912), the National Government Ministry of Education enacted "Normal procedure" in the drawing courses listed art history courses. Subsequently, art history courses in art institutions have opened. So far, the development of Chinese art history teaching, research, and is closely related to the cause of Chinese art. [1] After the founding of the PRC, with the development of higher art education and art creation, as the cause of the flourishing art archeology, on the one hand presents new culture art history and theory of objective needs, on the other hand also has opened up unprecedented possibilities for art history research. It is under this kind of historical conditions, the first department of art history was established by Central Academy of Fine Arts in 1957. However, with arts and crafts, art and design professional meteoric rise, traditional arts and crafts in the history of Chinese art and art design professional teaching it looks to be "outdated", it has become the main target of structural adjustment programs.

\subsection{Problems urgently need to be solved in Chinese art history course}

After the founding of new China, China's higher education owes much to the Soviet model of higher education, emphasizing professional education due to the special international political environment. In 1952, national college major experiences fundamental adjustments, forming a number of relatively-independent professional institutions. [2] In the special period undone, 
emphasizing professional training is in line with China's national conditions. But over time, especially since the reform and opening up, more and more obvious drawbacks of specialized education came in to being, so authorities began to re-examine and gradually adjust the professional setting of higher education. Many of Science and Engineering Academy have been reconstructed or newly opened humanities disciplines. At the same time, Guangming Daily, CCTV Science Channel and other mainstream media also attached great importance to publicity and education work in the humanities. However, after giving little attention for Humanistic Education, we would find that, on the one hand humanities education was strengthened in many colleges and universities, on the other hand, universities humanities education is faced with various difficulties.

\section{History of Chinese art history courses}

\subsection{Settlement of the course in the Republic times}

The initial stage of Chinese art history teaching was the same as other courses in the modern sense, which are for saving China through education, teaching and research activities that are part of patriotic teaching; curriculum is always closely related to social, political and cultural backgrounds. At that time, since a considerable part of the researchers of Chinese have been long engaged in teaching Chinese art history, class handouts of them become the prototype of Chinese art history textbooks. Whether it is art or history compiling style, they all laid in the preparation of paradigm in modern Chinese art history, and created the power can not be overlooked. However, because course was still in its infancy, Chinese art history and teaching materials prepared at this time to varying degrees by the impact of traditional painting theory, specifically in the curriculum at this time some of the art institutions tend to substitute art history with the history of painting, teaching materials are also part of the history of painting. [3] Currently, some institutions of higher learning of Chinese fine arts and art history teaching materials prepared by the history of painting, which is still the main cause of any of the course content.

\subsection{New development of the course in the early days of PRC}

After the founding of new China, the party and government attach great importance to the development of higher art education. In addition to "East China College of Art" and other historic institutions in Chinese art history, this course were set up in some newly established College of fine arts and a number of normal universities. Because of the particular social, political reasons, Chinese art curriculum goals and curriculum content reflects the distinctive characteristics of the times.

\subsection{Evolution of the course since reform and opening up}

Since the reform and opening up, China's higher education achieved a historic transformation. Higher art education has entered a new historical period. Since 1992, the State Bureau of Technical Supervision issued the "People's Republic of China subject classification and coding standards" from which point of view, in order to meet the needs of social development, fine arts covers art history, art theory, painting, sculpture, fine arts other subjects, technology art, craft art history, arts and crafts theory, the environment, arts and crafts to other disciplines, calligraphy, calligraphy history, theory of calligraphy, calligraphy other disciplines, photography, history of photography, photographic theory, photography other disciplines, there have been many new professional direction. 


\section{Dilemma faced by Chinese art history courses}

\subsection{Curriculum developers has no clear course objectives, with inadequate attention}

From the Chinese Art History we can see that at the beginning of higher art education, including Chinese art history courses, including art history courses in art institutions and art faculties Normal Universities and Colleges of Philosophy and Foreign and other disciplines, are clearly defined. Even in the late 1940s Liberated Yan'an Lu Xun Art Institute of Fine Arts Department of the curriculum, the history of Chinese art and Western art history courses are compulsory. [4]After the October 1949 founding of New China to the "Cultural Revolution" broke out, foreign art history lesson in art remains essentially is compulsory in Normal Universities and Colleges of Fine Arts Department in just teaching content due to the social environment, there are many taboos.

\subsection{Students has no clear learning goals}

To understand the purpose of students that currently learning Chinese art history courses, the author conduct a sample survey of 100 Painting, Sculpture professional students in Nanjing Art Institute of Fine Arts.

Generally speaking, by learning Chinese art history course, it is required that "fine arts students with the knowledge of the system as a Chinese art history art workers must have, in theory quality and culture has also been a corresponding increase, while his artistic training thinking ". However, from the questionnaire analysis 100 Academy of Fine Arts in painting, sculpture, it was found that many students don't have clear purpose of learning Chinese art history course. $35.8 \%$ of students learning Chinese art history just to get inspiration, $46.4 \%$ of students said they hope to improve their theoretical training by learning Chinese art history, while only $7.1 \%$ of the students hope Chinese art history learning and training their artistic thinking. Innovation is the essence of arts, and the first artistic innovation and innovation depends on the artistic thinking. Student learning objectives are not clear, which of course will affect the way they treat the attitude of this course. According to the survey, among the above 100 Academy of Fine Arts in painting, sculpture students, $28 \%$ of the students study the history of Chinese art of does not help their own creation, $32.7 \%$ of the students thought that Chinese art history should be elective courses.

\subsection{Faculty is weak}

Since some art institutions didn't give enough attention to the basis of professional theory courses Chinese art history, coupled with the increasing number of students in recent years, many art institutions are busy with graduate teaching and research, no longer serve as the basic undergraduate teaching jobs. Instead, some students just graduated took the place of undergraduate teaching, although these young teachers have a better professionalism, received some academic training, but after all, art history is an art history humanities, its teaching and research need is long period of exploration and accumulation. From this perspective, compared with the 1980s and 1990s, including the Chinese art history faculty, including basic theory course, the faculty was not strengthen but weaken to some extent.

\section{Main reasons for the plight of Chinese art history courses}

\subsection{The course has not clear positioning}

Fine arts Chinese art history courses in institutions of higher education, for painting, sculpture and other fine arts professional it is both general basic course is basic course; while for art and design, industrial design, fashion design and engineering, animation and other large professional art is concerned, art history is the basic courses, such as engineering students are required of mathematics, 
physics, cartography and other courses; and the history of painting, sculpture, history, history of design, animation, history and other topics is the nature of the course with a professional orientation. Basic course of action is for students to acquire specialized knowledge, learning science and technology development related to their ability to lay the foundation generous, but also train specialized personnel required courses.

\subsection{The basic theory courses are unappreciated}

For a long time, we are used to dividing school curriculums to be main subject and the sub-classes. For example, the compulsory courses in universities, the Chinese, Mathematics, Foreign languages like beauty, body is usually considered to be minor subject. Originally the school curriculum sub-main and secondary classes and beyond reproach, but the problem is that bias exists that some students and even teachers deputy Course "Sub" word in understanding, with which opinion, they think the minor subject is unimportant course, and even some teachers and students that learning deputy courses will take time to learn core subjects. [5]In fact, the only means minor subject curriculum majors outside of course do not mean that is not important. Many scientists, inventors of successful experience tell us that if there is no nourishment of "minor subjects", the "main course" will become the one with no "source of water." It is visible that though minor subject is not the main subject, but it is important because it relates to the overall development of human beings and the overall quality and improves the comprehensive competitiveness.

\subsection{The course has no clear goal}

Positioning of some universities mentioned art professional Chinese art history course is not clear and unclear positioning of course curriculum often lead to unclear target of the curriculum.

From the teaching materials major collected form domestic and Design Institute of Fine Arts collected, most of the objectives only have training purpose while with no curriculum objectives. In general, the goal is to train general training requirements for a professional orientation of students, but in the direction of the target in relation to the professional backbone which students should make brief lesson on the provisions of a specific target without involving curriculum course. Thus, the training objectives are irreplaceable for curriculum objectives, curriculum objectives are with more concrete meaning, which has direct implications for guiding the implementation of the curriculum.

\section{Ideas for art history teaching reform}

\subsection{Positioning of Art History Course}

According to the high-quality and specialized personnel training objectives in the 21st century, the Ministry of Education requires all colleges and universities General Education and Special Education should be combined in the educational process, and determine the content of teaching science and rational curriculum. For Teachers Colleges of Fine Arts faculties in terms of the general domestic and foreign general history course in teaching arrangements are very difficult, but set up Chinese and foreign art history course History of nature is feasible, it can compensate for the lack of knowledge of foreign history, but also art history and grasp the law of development from the macro to guide us today to learn and practice the art. Therefore, in the context of university general education reform, positioning art history courses into basic course is necessary. In order to achieve the purpose of art education, schools at all levels need to set clear training objectives according to the actual situation.

\subsection{Art History Teaching Management Reform}

Art Education Management is the concrete application of management science in this particular field of art education, is a study of arts education management phenomenon, revealing a new 
discipline of art education management inherent law. Research scope of Art Education Management include: arts education administration, arts education in schools management, teaching arts management, arts teacher management, arts leaders and social institutions of their own management and many other aspects of arts education management. For art history course, the big management agencies Secretary to the Ministry of Education, from teaching faculty leadership and administration to small institutions at all levels, their ideas, measure, evaluate and so on will directly affect the implementation of the course.

Art History course got into such an awkward situation was in a certain relationship with the school teaching management mechanism. For a long time, Normal Colleges of Chinese attached great importance to mathematics and foreign languages, and other key departments and discipline, while for music, art and other smaller less attention was given. Most school leaders and leaders in charge of the Office of Academic Affairs Teaching drawn from so-called several major departments, school leadership for teachers from art departments is very few. Although school leaders are with strong management, they are still unfamiliar art disciplines. Therefore, in daily teaching supervision, some school leaders take regular education management discipline of art, while the result is often counterproductive.

\subsection{Art History Curriculum Reform}

In the field of education, selection and organization of curriculum content preparation process is an important part of the curriculum, which has always been highly valued. In the traditional teaching way, course content to student are treated as the acquisition of knowledge, and transfer carrier of knowledge is based on teaching materials, so the course content is rightly considered to be used in class teaching. "

Currently, art history textbooks used in domestic university courses are the same, but some textbooks ignore the professional characteristics and the actual needs of various groups, difficult to play a potential value of art history course and effect. Mr. Li Puwen said: "The problem is not one two materials we need, what we need is to adapt to different teachers and students of different art history textbook, and that these materials should be produced from art history teaching practice, and be adjusted and strengthened with the changing practice of teaching art history at any time. "

\section{Summary}

As a basic course, art history course on the one hand is capable of improving the students' cultural quality and aesthetic ability, which can stock some necessary knowledge and ability for their basic art teaching in the future; on the other hand, art history courses, can guide students in professional writing. Besides, it also plays an important role in promoting the teaching and research capacity.

\section{References}

[1] Yin Shaochun. Art and Education [M]. Changsha: Hunan Fine Arts Publishing House, 2013

[2] Pan Maoyuan. College Teaching Principles and Methods [M] Beijing: People's Education Press, 2014.

[3] Xu Rong. Standard Chinese art history course [M]. Shanghai: Shanghai Fine Arts Publishing House, 2015

[4] Shi Liangfang. Curriculum theory - basic courses, Principles and Problems [M] Beijing: Education Science Press, 2015

[5] Xianzhang. Chinese Modern Art Education codification [M] Beijing: Education Science Press, 2014 